\title{
Piecing together a College Education behind Bars
}

Jon Marc Taylor

$\mathrm{T}$

This article sets forth the reasons for prisoners to pursue the personal quest for a college education. It discusses how equivalency-credit programs can accelerate the pace of that pursuit while decreasing the costs; end-ofcourse exams and credit bank schools can coalesce divergent academic experiences, and pulling it together by filling in with life-experience credits and relatively inexpensive correspondence courses to fulfill the chosen curriculum. While this article is directed towards incarcerated students in the United States, traditional students may find the advantages applicable. For academics, the article offers a practical method of higher education delivery in the penal setting, and for students and teachers it is an affirmation of the value of post-secondary correctional education (PSCE).

A wise man once advised: "If you want to make the world a better place, begin by making yourself a better person." To begin that process behind bars, start by reconstructing self-worth devastated by poor personal decisions, and by systemic devaluing abuses leading to this position in your life.

Education is the single most significant program on this journey of selfdiscovery, individual revelation, and personal transformation. Beyond the necessary achievement of a high school or GED diploma (in many jurisdictions in the United States, the GED is required to qualify for parole consideration), earning a college degree not only creates the best chance to stay out after release, it is also the best way to qualify for a decent job and to become equipped with skills for successful re-integration.

Half-a-dozen years ago, most department of correction systems in the United States offered on-site higher education opportunities. Then, for political expediency, the U.S. Congress barred prisoners from receiving their chief tuition source, Pell Higher Education Grants. Almost immediately, half the prison college classes across the country were closed, and opportunities in most surviving programs were reduced as well. Today, the only access the majority of convicts have to post-secondary education is through traditional correspondence classes, less well-known university end-of-course exams, and even less publicized equivalency tests.

This article presents options to access higher education behind bars, while keeping the process as inexpensive as possible. This article points out the least expensive means to a college degree without the financial aid from Pell Grants. The first section, however, reinforces the efficacy of PSCE in your life. 


\section{THE VALUE OF HIGHER EDUCATION}

The most certain but most difficult way to prevent crime is to perfect education.

Cesare Beccaria, On Crimes and Punishment, 1764.

\section{Recidivism}

The value of PSCE programming cited most often in the literature is that it significantly lowers the likelihood of returning to prison. Typically, recidivism drops from seventy percent of parolees being rearrested to twenty percent for those who earned an associate (i.e., two-year) degree, or more. Two decades of $\mathrm{PSCE}$ recidivism studies consistently report "statistically significant" reductions in recidivism. Robert Ross analyzed prison college programs in his article "Behavioral Approaches to Treatment in Corrections: Requiem for a Panacea." He summed up these studies by observing that "nowhere else in the literature of correctional programming can one find such impressive results with the recidivistic adult offender" (Ross and McKay, 1978: 290). ${ }^{1}$

\section{Employment}

Parole officers identify unemployment as a prime factor in recidivism. On average, less than half of ex-offenders find steady employment when paroled. Every study on the issue has found that college educated ex-offenders are the ones who find steady employment (Ayers et al., 1980; Harer, 1995; Holloway and Moke, 1986). Besides overcoming the stigmatization of being an ex-felon, the majority of jobs in today's service economy require the skills of a collegeeducated person. Without a college degree, or at least some post-secondary course credits, menial work at minimum wages is the most likely option for

1 The State Correctional Institution (Pittsburgh, Pennsylvania) study on PSCE found that "inmate students with the highest risk of recidivism experienced a statistically significant ... reduction in recidivism when compared to the control group on 108 variables" (Blumenstein, A. and Cohen, J., 1979). The Texas Department of Corrections Treatment Directorate showed that "participation in the junior college program definitely results in lower recidivism rates" (Gaither, 1980). Participants in the New York Department of Correctional Services PSCE programs demonstrated a twenty-six percent recidivism rate compared to a forty percent overall rate (Clark, 1991). Also see Duguid (1981), Harer (1995), and Holloway and Moke (1986). 
the ex-con. And for the uneducated, newly-released prisoner, Princeton University professor Bruce Western reports that the average parolee starts out making ten to thirty percent less than high school dropouts without criminal records (Western and Pettit, 2000).

\section{Earnings}

In today's workplace, those who earn at least some college education or post-secondary vocational training are far more likely to find employment that supports a decent standard of living. For the average adult, the annual rate of return on the money and time invested in four years of college is about eleven percent (University of Wisconsin, 1995). For the paroled prisoner, it is immeasurably greater. In 2000, the average salary for a worker with a fouryear Bachelor degree was $\$ 50,000$ (Armour, 2002), and over a working lifetime the degree is worth more than $\$ 1.6$ million in additional income over that of a high school diploma (Haralson and Tian, 2002). Even in markets with above average unemployment levels, the college educated ex-convict stands the best chance for a job providing a living wage.

\section{The most important reason}

The single most important reason for anyone, but especially a prisoner, to pursue a college education is how it will make him or her feel. Regardless of the date you walk out of the prison and "sally port" to freedom, further education will improve confidence and self-esteem, and improve how you feel about and treat others. Higher education imparts the abilities to analyze, reason, and think for yourself in any situation. As a powerfully liberating tool, it can never be taken away; it can only be ceded by your choice not to utilize those skills.

\section{Benefits for society}

What PSCE means to society is reduced crime and thus safer communities; economic stimulation provided by better educated, productive, and higher paid workers; and the cessation of the prisoner as a tax liability to a taxpayer. Simply put, the average income of a college graduate compared to that of a high school graduate results in thousands of dollars in annual tax revenues. Beyond these quantifiable benefits, the transformational effect of higher education in the evolution of a more rational and informed citizen strengthens a democratic society. ${ }^{2}$ 
"A wise man will make more opportunities than he finds."

Francis Bacon

The next section covers various types of equivalency examination programs recognized for credit by more than two thousand universities and colleges in North America, and exam preparation suggestions for the best chance to succeed with these savings.

\section{HOW EQUIVALENCY CREDIT PROGRAMS CAN REDUCE COSTS}

The single biggest expense of earning a college degree behind bars is the cost of tuition. At present, the average undergraduate tuition fee in the United States is $\$ 125.00$ per credit hour. A two-year Associate degree requires an average of sixty semester credit hours, and a four-year Bachelor degree requires a minimum of 120 semester credit hours. By this general outline, tuition fees alone will average $\$ 7,500$ for an Associate degree, to more than $\$ 15,000$ for a four-year degree. The pain, however, does not end there. Aside from several hundred dollars in incidental costs (e.g., enrollment, term registration, shipping and handling expenses, and graduation fees), there is the cost of texts. Books will be the second greatest expense in earning a degree in the joint. On average, a student can expect to spend $\$ 90.00$ per course for the necessary texts and study guides. With twenty classes for an Associate degree and forty classes for a Bachelor degree, an individual should expect to spend an additional $\$ 1,800$ to $\$ 3,600$ for textbooks.

All told, even with "room and board" and medical (such as it is) paid for by the state, earning a college degree behind bars using only traditional correspondence course opportunities will cost from $\$ 9,000$ to $\$ 20,000$. That

2 For more information on the efficacy of PSCE, see the following sources: Cotter, M. et al. (1997, September). Education as Crime Prevention: Providing Education to Prisoners. Research BriefNo. 2. Available free from the Center on Crime, Communities and Culture, 400 West 59 $9^{\text {th }}$ Street, New York, NY 10019. Cypser, R. (1997, 21 October)."What Works in Reducing Recidivism, and Thereby Reducing Crime and Costs?" and "The Pay-Back in Reducing Recidivism and Thereby Reducing Crime and Costs." Available free from CURE New York, Box 102, Katonah, NY 10536. Williford, M. (Ed.). (1997). Higher Education in Prison: A Contradiction of Terms? Available for $\$ 35.50$ from Oryx Press, 4041 North Central Ave. Suite 700, Phoenix, AZ 85012-3397. Phone 1-800-2796799. 
may not be a problem if a person has extensive personal resources or a generous supporter. The purpose of this article is to show how one can piece together a college degree for less than $\$ 2,000$ and a Bachelor degree for much less than $\$ 5,000$. Admittedly, this is not cheap in the penitentiary, but it is possible to finance if it is spread out over years. If there is one thing we prisoners have in abundance in the American "gulag archipelago," it is time on our hands.

\section{Equivalency programs}

Literally thousands of colleges and universities in North America grant credit towards their degree programs based upon various "testing services" examinations. These tests are meant to represent the final exam in a particular college course. Individuals who pass the test with a high enough score (which may vary from school to school) can be granted equivalent credit as if they had taken the complete class at full cost. For one-tenth of the expense and a month of intensive study, you can document "transferable" college credits applicable to virtually any degree program you choose.

Few schools, however, will grant degrees singularly based upon exam credit accumulations; therefore, it is usually necessary to enroll in one-quarter of the required degree hours at whatever college you are seeking a degree from. This means you will have to juggle university-level credits from various sources and take some traditional correspondence courses to earn your degree. It is well worth the effort. Considering our original projection of $\$ 20,000$ for a Bachelor degree, imagine earning three-quarter of that baccalaureate at next to no cost.

Three major testing services administer exams (CLEP, DANTES and Regent College Examinations). ${ }^{3}$ These are offered at testing centers all over the U.S. on many dates year round, and all have procedures for institutionalized individuals to participate. You will need to work with your prison's education office to coordinate the testing process, but these exams are not significantly different

3 The major testing services and their exam fees at the time this was written (2003) were: CLEP EXAMS, P.O. Box 6600, Princeton, NJ 08541 which charges $\$ 46.00$ per credit hour; DANTES Program, P.O. Box 6604, Princeton, NJ 08541, which charges $\$ 35.00$; and the Regents College Examinations (formerly Excelsior College Examinations), 7 Columbus Circle, Albany, NY 12203 , which charges $\$ 40.00$ or more per credit hour. The testing services provide lists of the topics and courses for which they offer tests. 
to proctor than standard correspondence finals. If your prison permits distance education participation there should be no problem.

\section{Testing services}

The value of testing service exams is that, for a small fee of usually less than $\$ 50.00$, it is possible to earn from three to thirty semester hours of academic credit. In our example, where one credit equals $\$ 125.00$, three credits would normally cost $\$ 375.00$, perhaps $\$ 400.00$ with texts. At $\$ 50.00$ for three to thirty credit hours, the savings are considerable!

Each college or university sets its own transfer credit policy on what courses and testing services' exams it accepts, and what grades and scores are required. When contacting a school it is necessary to ask: (1) what exam services are accepted and in what subjects; (2) what scores are needed for equivalent credit; (3) if accepted, do such credits allow you to skip one or more introductory courses; and, (4) are there any additional requirements before credit is granted?

Over 2,800 colleges and universities recognize the College-Level Examination Program (CLEP). It is probably the most respected and accepted testing service, as it is backed by the century-old College Entrance Examination Board. Over four million students have utilized the CLEP program, and these are challenging and comprehensive exams. Credit is earned only if you can demonstrate concentrated subject knowledge acquired through prior or independent study, through cultural pursuits or special interests, or through professional development, such as in a military occupation specialty or company training programs.

CLEP exams cover subjects from business to science, offering five General Exams and twenty-nine Subject Exams. The General Exams cover material taught in courses that most students take as requirements in the first two years of college. Each test is ninety minutes long, and except for "English Composition with Essay," they consist entirely of multiple-choice questions to be answered in two separately-timed sections. Six-semester hours of credit (in our formula, worth approximately $\$ 900.00$ ) are usually awarded for satisfactory scores on each General Exam.

Each Subject Exam covers material taught in an undergraduate course with a course name that is similar at most colleges and universities. A college usually grants the same amount of credit to students earning satisfactory scores on the CLEP exams as it grants to students completing the same course at its 
school. Many Subject Exams are designed to correspond to one-semester (three-credit) courses; however, some correspond to full-year (six-credit) or two-year (twelve-credit) courses.

"DANTES" Subject Standardized Tests (DSST) is a nationally recognized testing program developed originally for military personnel, thus the acronym DANTES (Defense Activity for Non-Traditional Education Support). This service provides the opportunity to receive college credit for learning outside the traditional classroom. Over 80,000 individuals take DSSTs annually. More than 1,200 colleges and universities currently award credit for DSSTs. There are thirty-seven different test titles to choose from, in the areas of social sciences, business, mathematics, applied technology, humanities, and physical science. While DSSTs are not timed, they usually last ninety minutes. They are multiple-choice tests with no scoring penalty for guessing.

Regents College Examinations (formerly known as ACT-PEP exams) have been offered for three decades and are accepted by nearly 1,000 colleges and universities. The forty-two multiple-choice, essay, and mixed format course exams cover the areas of arts and sciences, business, education, and nursing, at the Associate and Baccalaureate levels. While Regent College Exams may cost up to three times the fee for CLEP and DANTES exams, the diversity of upper-level courses and nursing specialty exams provide testing options that these other services do not. The Regent exams are worth considering for junior and senior level students, or for those who are only a few credits short of graduating.

\section{Putting together an exam strategy}

As you can see, these exams can save a significant amount of money in earning a number of college credits. Moreover, the testing services have fee waiver programs for "special situation" individuals, which can include prisonerstudents. The CLEP program in particular grants waivers to prisoners; however, these services have a limited budget for exemptions. Since they are available on a first come, first served basis, it is necessary to apply early in the year for the best chance of fee waiver approval. If denied by one service, apply to another. Remember: "no" means "not now," not forever.

Even with free testing, study materials present another expense. Each of the services (see Note 3 ) offers free fact sheets and study guides along with sample questions. CLEP charges \$18.00, and Regents College Examinations charge $\$ 18.95$ for comprehensive study guides covering all of their thirty-plus 
exams. These guides include sample questions, test-taking tips and answer rationales for multiple-choice exams, procedures for getting university credit, and study resource recommendations.

Through these recommended study resources it is possible to save yourself even more by creatively managing access to the preparation textbooks. Each study guide suggests half-a-dozen of the routinely-used classroom texts covering the exam's material. First, check the prison library. Most libraries collect various texts (e.g., sociology, psychology, mathematics, history, physics, and literature anthologies). If your library does not, you should start requesting that it acquire them, specifically suggesting the titles listed in the study guides.

Secondly, once newer editions of these textbooks are issued (about every three years), the previous editions are discounted by the publisher. For a few dollars yon can pick them up from closeout catalogs without significantly sacrificing information covered on the exams. There are also several specific preparation guides and learning packages published with full-length sample tests. Request that your librarian order these as well. Thirdly, working through your librarian or education director, form a committee that will write to area colleges and universities seeking donations of departmental and professors' discarded texts. We built cost free a multi-thousand volume reference library for the Ball State University program at the Indiana State Reformatory with this or a similar donation strategy.

From test-fee waivers, free study guides, to off-the-library-shelf textbooks, you can earn anywhere from three to ninety (to even possibly all the necessary) credit hours applicable to a degree program at virtually no cost. Using a little bit of timely hustle by applying for fee waivers early in the term, and using creative management of your prison library (even if you have to stock it yourself), you can piece together the major portion of your degree's required course hours for no money. By forming a study group in your joint, not only can you increase prospects for passing the exams, you can leverage available resources with the collective power of your brain trust. You can begin by collecting the hundred-plus free study guides from the CLEP, DANTES, and Regents College examination services, which will serve as the foundation of your reference library. The rest is limited by your capacity to dream.

Finally, just how difficult are these exams? Dr. John Bear relates in his many books on distance education that this is a subjective question. People comment that these exams are "a lot easier than they had expected." This is truer for mature, life-experienced students, than it is for eighteen year-old high 
school graduates. Cramming has been proven to be an effective study strategy for some. Bear tells of a man who crammed for, took, and passed three general GRE exams, earning the equivalent of ninety credits. The man then took five CLEP General Exams in a row, earning an additional thirty-hours. Applying them to an accredited school, he received a Bachelor degree for less then twenty hours of exam time. Admittedly, it is an extreme example, but it is effective and demonstrably possible (Bear and Bear, 1999).

Do some research, collect your materials, take the self-scoring sample tests, and see how you do. If you do well, go ahead and take the exam. If you score "so-so," read the texts, do some cramming, and write the exam again. If you fail miserably on the sample test, perhaps other means outlined in the rest of this article may be more favorable to earning you a college degree.

If you take an exam and do not score high enough for credit, you can retake the same subject exam again in six months-all the wiser for your experience. Never give up. Never surrender your future. In the words of Marabel Morgan, "Persistence is the twin sister of excellence. One is a matter of quality; the other, a matter of time."

\section{END-OF COURSE EXAMS, LEARNING PORTFOLIOS, AND CREDIT BANKS}

Credit-equivalency exams probably provide the best dollar for dollar value. However, for most people these exams will not meet the entire course requirements for most degree programs. Other credit accumulation options exist, and this section outlines them.

The traditional way to fulfill these last few class requirements (even for on-campus students) is to enroll in standard correspondence courses, submitting a dozen or so lessons and taking on average two proctored exams for each course. This option will be covered in the final section of this article. In keeping with the overall strategy of piecing together your college education as inexpensively as possible, and to earn a degree in the shortest amount of time, end-of-course exam options, prior learning portfolio accreditations, and credit bank services are reviewed next.

\section{End of course exams}

End-of-course exams, also called "course credit-by-examination" among other labels, are similar to CLEP and DANTES exams, except in this case the credits granted are usually for a more specific course in a college curriculum. 
This method is of particular use when one or a few defined classes are necessary to fill out the requirements of a degree program.

These exams are basically the same tests used in the courses, although sometimes the correspondence course's two standard exams are collapsed into one. The value in utilizing this option is in reduced expenses and time invested. In the typical situation, the expense of credit-by-examination courses is from one-third to one-half of a traditional per credit hour enrollment costs.

In most programs you can enroll in these courses (which at some schools are the same courses available for traditional correspondence study), purchase the study guide, syllabus and texts, and schedule the end-of-course exams when you are ready. There are no assignments or midterms to complete. You study to prepare to pass the single end-of-course exam. For most students, the selection of a particular class using these means is based upon some prior knowledge of the subject, as well as a particular need for the transcript credit; usually to fulfill a minor or major area of study.

Employing strategies similar to Credit Equivalency Exams, the associated expenses can be reduced further. Used texts can be purchased, books on similar topics can be pulled from a library shelf, and a couple of you can take the same credit-by-examination course in order to split the material fees. Furthermore, if you add these materials to your resource library you are constantly expanding the opportunities for those following in your trail-blazing footsteps, motivated by your example.

\section{Prior Learning Assessment}

Prior Learning Assessment (PLA), also called "experiential learning" or "life-work experience," can be a time and money saving way to accelerate your advancement toward a college degree. PLA is how the scholastic world is acknowledging that many students have a level of work experience and life knowledge that should be recognized for credit. Over 1,000 schools offer PLA. The central principle that underlies assessment of work or life experience is that what students know is more important than how they learned it. If students can demonstrate that their existing knowledge and skills are reasonably comparable to those of college-trained students then comparable credit is awarded. Credit is usually obtained through the process of writing a "portfolio" which summarizes and documents the student's knowledge.

Not all life learning can be converted into collegiate credit, but you will be surprised how much of what you already know is indeed credit worthy. There 
are eight major categories that may yield college-equivalent credits. These are: (1) work (skills and activities performed on the job, including military service); (2) homemaking (maintenance, planning, budgeting, child psychology, cooking, and nutrition); (3) volunteer work (church activities, political campaigns, service organizations such as Jaycees and Toastmasters); (4) non-credit learning in formal settings (business training courses, clinics, conferences, lectures and workshops); (5) travel (tours, business trips, significant vacations, living abroad); (6) recreational activities and hobbies (acting/community theater productions, arts and crafts, aviation training, gardening and landscaping, musical skills, etc.); (7) independent reading-viewing-listening (extensive or intensive self-directed study); and (8) conversations with experts.

To receive credit for these experiences you must construct a Prior Learning Portfolio. A portfolio is a written report justifying and documenting your request for college-equivalent credits. It is not an easy task, but it can be well worth the effort. Many schools provide instructions on how to compose your portfolio. Portfolios have four components: (1) a request for specific course credits; (2) a resume identifying your educational, professional, or other relevant activities; (3) a narrative demonstrating that you have college-equivalent knowledge and skills; and (4) documentation to support your claims of accomplishment. ${ }^{4}$

It is crucial that you are able to document your life experiences. An assessment team at the school will evaluate your portfolio. Criteria used to evaluate your portfolio includes, but are not limited to, the amount and level of decision-making responsibility; reporting relationships with subordinates and colleagues; the span of financial control; the duration of training experiences; and the overall level of responsibility required. Schools and the American Council on Education (ACE) are striving to create "menus" of uniform credit awards for non-traditional experiences. ${ }^{5} \mathrm{ACE}$ publishes two massive books making such recommendations: The National Guide to Educational Creditfor Training

4 Examples of possible creditworthy activities include: playing tennis, leading a church group, taking a body-building class, reading War and Peace, writing a book, navigating a small boat, watching public television, being a camp counselor, playing in a band, repairing a car, performing magic, writing a speech, organizing a union, and devising a marketing strategy.

5 Selected examples of standardized awards are Alcohol and Drug Counselor (6 credits), Basic Red Cross Lifeguarding (1 credit), Basic Literacy Volunteers of American Tutor Training ( 3 credits), Emergency Medical Technician (4 credits), Fluency in Spanish (24 credits), Legal Clerk, Army MOS (24 credits), and Water Safety Instructor ( 2 credits). 
Programs and Guide to the Evaluation of Educational Experiences in the Armed Forces. Urge your education director or librarian to order these reference guides for your educational resource library. ${ }^{6}$

Many colleges and universities offer portfolio credit evaluations. The number of credits possible to earn range from a few to over one hundred, depending on students' backgrounds and their effectiveness in preparing portfolios, as well as the school's particular policies. Evaluation fees vary from college to college. They usually range from a few to several hundred dollars for registration and evaluation, and on average, from $\$ 31.00$ to $\$ 60.00$ per credit hour granted and listed on the transcript.

\section{Credit Bank Schools}

Schools that have unrestricted transfer and portfolio credit granting policies are also called "Credit Bank Services." These fully accredited schools work like a money bank accepting deposits of academic credits. Regardless of where the credits are earned, they issue a single, widely recognized consolidated transcript. These schools also offer a wide variety of degree programs. ${ }^{7}$

There are seven basic categories of learning experiences that can be deposited in credit bank accounts. These credit sources can be mixed and matched to fulfill a majority, and in some cases all, of the necessary hours to complete a degree's requirement. These seven categories are: college courses, either classroom or correspondence; equivalency exams; military service occupations training and experiences; ACE accredited industry training programs; FAA pilot certifications and licenses; nursing performance examinations; and all other life experiences coalesced in a portfolio assessment.

6. For PLA guidance materials contact: Earn Creditfor What You Know, L. Lamdin, Council for Adult and Experiential Learning, 55 East Monroe Street, \#1930, Chicago, IL 60603. This publication sells for $\$ 24.95$ plus tax. Ask for additional publications. Portfolio Video Seminar \& Printed Study Guide, Follet's Bookstore, Governors State University, Illinois, 1-800-GSU-8GSU, ext. 4588. Experiential Learning Guidebook by W. Kemble, National College Studies, Student Assistance Division, Dept. BG1, 675 Blue Mountain Road, Saugerties, NY 122477.

7 Over 200 undergraduate areas of degree granting diplomas are offered by the following three colleges: Charter Oak State College, 55 Paul J. Manafort Dr., New Britain, CT 06053-2142; Thomas Edison State College, 101 West State Street, Trenton, NJ 086081176; and Regents College, 7 Columbia Circle, Albany, NY 12203-5159. 
For students with diverse training and life experiences, credit banking services provided by these profiled programs could be an excellent investment. Banking allows you to pull together all the creditworthy accomplishments you have earned. Even students with limited life experiences and extensive credits earned via widely accepted equivalency exams can benefit, if not necessarily from the credit banking services then from the liberal acceptance of transferred credit hours towards these schools' degree granting programs.

Fees vary among these services. Portfolio assessment fees range from $\$ 250.00$ to $\$ 600.00$, with per-credit-granted rates from nothing to $\$ 100.00$. Annual records maintenance fees average another $\$ 100.00$. With deft timing (i.e., applying when enough total hours have been accrued) these service fees can be avoided by immediately applying for a degree. For those directly seeking a degree, rather than credit banking services, the Charter Oak State College Foundation offers grants of up to $\$ 500.00$ per student for courses, tests and portfolio assessment fees. Apply early for this generous waiver program.

For those able to submit credit deposits of 120 academic certifiable hours or more, a baccalaureate could be earned for around $\$ 500.00$. This is quite a savings over the initially projected cost of $\$ 20,000$ for a degree earned via traditional correspondence studies. Only your imagination limits your creative uses of all of these resources to achieve your degree. In the words of Marcus Garvey, "According to the commonest principles of human action, no man will do as much for you as you will do for yourself."

\section{Curriculum CONSTRUCTION, "BEST BUYS," AND PULLING IT ALL TOGETHER}

In any institutional setting, pursuit of a higher education is an arduous task. The quest of a college degree via distance education is especially difficult with all the attendant rules, regulations, and policies of the schools, the department of corrections, and even of the particular prisons. You have many masters, but only you are the captain of your fate. To undertake such a dream, you must plan a step-by-step approach.

The first task is to collect and review your institution and system's policies regarding distance education enrollments as well as associated regulations (e.g., personal property restrictions). These will provide the parameters within which you will have to construct your course of study. Contact your prison's education supervisor and see what assistance and service he or she can provide. The education administrator can be your best ally by smoothing out the inevitable 
glitches, or your worst bureaucratic nightmare by obtusely or even malevolently failing to manage your education program.

\section{Curriculum construction}

The next step in your goal of a college degree is to plan your course of study. It is the responsibility of the distance education student to design a curriculum that fulfills the desired degree requirements.

To be able to design your curriculum (i.e., the courses you need to take) you have to know what degree you want to achieve and where you want to earn it. It is a decision that should take into account many factors. These include: the number of transfer credit hours permitted towards degree requirements (the more the better), the acceptance of equivalency exam and portfolio credits (the more liberal the better), and the tuition fee per course hour (the lower the better).

There are two basic types of undergraduate degrees: Associate of Arts or Sciences, which is generally a two-year degree requiring from fifty to seventy semester-based credit hours; and a Bachelor of Arts or Sciences, generally a four-year degree, requiring from 120 to 130 semester-based credit hours. The Associate degree provides a basic or foundational college education, with "science-oriented" degrees fulfilling specific technical training, such as advanced automotive or computer certifications. The Bachelor degree is built upon the foundation of an Associate degree, and provides two additional years of morefocused education in major or dual minor areas of study.

My recommendation, based upon the enlightenment of the personal experience of 180 credit hours, observation of hundreds of other prisonercollege students, and intense scholastic research, is to take as many diverse types of courses as possible within your limited circumstances and permitted by the latitude of your chosen degree curriculum. All schools provide curriculum counselors. Be sure to use their services and have their approval for your chosen curriculum. ${ }^{8}$

8 A generic curriculum for an Associate of Arts degree includes Basic College Skills (6 credits), Arts and Humanities (12 credits), Natural Sciences (9 credits), Social Sciences (12 credits), Mathematics ( 6 credits), English and Composition (9 credits), and Electives (9 credits). For a Bachelor of Arts, the typical curriculum is Basic College Skills ( 9 credits), Humanities ( 9 credits), Physical Sciences ( 6 credits), Mathematics ( 6 credits), English and Composition (12 credits), Social Sciences (15 credits), Foreign Language (6 credits), Electives ( 9 credits), and 48 credit hours in a major field of study (e.g. sociology, anthropology, physics). 


\section{"Best buys" in correspondence study}

In the vast majority of cases, no matter how many equivalency-exam and life-experience portfolio credits you have been able to achieve, you will need to complete a minimum of five (for an Associate degree) to ten (for a Bachelor degree) three-credit hour courses by correspondence from the college or university from which you are seeking a degree.

Actually, this is a good thing. In prison there is nothing quite as satisfying as successfully completing the struggle to earn a grade in a college course. The feeling of enhanced self-respect and self-worth you achieve from your own efforts to overcome all institutional and intellectual obstacles to complete a class is like no other self-satisfying rush! The exception may be winning your pro se written brief before the Supreme Court, but how many of us get a chance to do that?

As mentioned previously, there are many factors to consider when selecting a school. Accreditation is an essential qualifier. Tuition rates are another important factor to consider but should not be the overriding qualifier. In Note 9, "Effective Rates" (ER) for tuition are listed by computing all administrative and registration expenses and tuition fees, averaged to an across-the-board comparable sum per credit hour. While tuition rates increase every year, the schools listed offer some of the "best buys" in the United States. ${ }^{9}$ Do not forget the other factors to consider in the school selection process, such as the flexibility of credit transfer and acceptance policies.

There are other colleges and universities offering tuition rates below the national average to consider as well. Indiana University, with a tuition rate of \$98.75 per credit hour, offers certificates, and Associate and Bachelor degrees with more than 200 correspondence courses. The university's international scholastic reputation and academic recognition makes it a program worth considering. ${ }^{10}$

9 Effective Rates (ER) at some "best buy" schools: Louisiana State University, Office of Independent Study, E106 Pleasant Hall, Baton Rouge LA 70803. 160 courses offered, ER \$63.33 per credit. Sam Houston State University, Correspondence Division, P. O. Box 2536, Huntsville, TX 77341. 37 courses offered, ER \$52.00 per credit. Southwest State University, Office of Correspondence Studies, 601 University Drive, San Marcos, TX 78666. 60 courses offered, ER $\$ 57.00$ per credit. Texas A\&M UniversityCommerce, Guided Independent Study, P. O. Box 3001, Commerce, TX 75429-3011. 30 courses offered, ER $\$ 60.00 / 75.00$ per credit. University of Arkansas, 2 East Center Street, Fayetteville, AR 72701110 courses available, ER \$63.00/73.00 per credit. 
Perhaps you wish to graduate from a school in your state, the home of your favorite college team, or the one from which your parents graduated. Whatever your motives, apply the suggested criteria balanced against your resources and select your future alma mater. Douglas G. Dean, who earned his Bachelor's, Master's and Doctorate at the University of South Africa while he was in prison-now that is distance education-observed, "When it all comes together, it is the greatest feeling in the world" (quoted in Bear and Bear, 1999: 178).

\section{Note on accreditation}

An important, basic factor when selecting a school is determining if it is "accredited." Accreditation by a US Department of Education recognized accrediting agency assures a student that the "accredited school" has met certain standards concerning the quality of education, faculty qualifications, appropriate text and materials, financial stability, and so forth. Earning course credits at one accredited school generally assures the transferability of those classes to another college.

There are six regional accrediting associations, and the Distance Education and Training Council (DETC), which generally accredit independent and proprietary schools. ${ }^{11}$ If a school is accredited by any of these associations, you can be assured of transferable credits and a recognized degree.

Recently, unauthorized or US Department of Education non-recognized accrediting agencies have been formed to "sell" essentially false credentials using "diploma mill" programs. The World Association of Universities and Colleges is such a private accrediting agency. Caveat Emptor-"Buyer Beware"-should be your watchword when picking a school. All statesupported colleges and universities must be accredited according to their charters. You would be well-advised to avoid an unaccredited school.

10 Consider programs at Indian University, School of Continuing Studies, 790 East Kirkwood Avenue, Bloomington, IN 47405-7101. See their Associate of Science in Labor Studies (60 credits), Associate in General Studies (60 credits), Bachelor of Science in Labor Studies and General Studies ( 120 credits each). Indiana offers 225 courses by distance. ER \$98.75 per credit.

11 US Department of Education Recognized Accreditation Agencies: Distance Education and Training Council, Middle States Association of Schools and Colleges, New England Association of Schools and Colleges, North Central Association of Schools and Colleges, Northwest Association of Schools and Colleges, Southern Association of Schools and Colleges, and Western Association of Schools and Colleges. 


\section{Pulling it all together}

Now you know your basic options. The next steps are to evaluate your life experiences, collect some equivalency-exam preparation booklets and texts, send for various schools' distance education materials, and start building your university curriculum towards your goal of a college degree.

The biggest difference in distance education is that you do not have the classroom experience, which usually provides an opportunity for face-to-face interaction with your instructor and other students. You will have to be even more self-reliant than an on-campus student. Your entire degree program rests in your hands. It depends on your creativity, determination, and motivation.

Whether you are preparing for an equivalency exam, end-of-course test, or regular correspondence lesson, you will need to establish some good study habits. First, set a time and place to study. You need a schedule, and the more strictly you can keep to it, the more likely you are to be successful in your studies. Eliminate as many distractions as possible. For example, when others are out of the cellblock for recreation, you study. You can block out the range's roar by learning to concentrate with headphones on. Second, set deadlines. Divide the amount of work required for your courses by the number of months you have to complete them. This gives you a schedule and a series of deadlines to guide your pace through the course work. Third, when you set up your study plan, allow some extra time for lessons to be reviewed by the instructor, and for assignments and exams to be graded and returned-not to mention the occasional "interruptions" in prison routine. Fourth, read your instructor's comments on the graded written assignments and exams. Ask additional questions and keep your returned assignments for study purposes. Here is a hint: many exam questions are derived from assignment questions.

\section{Conclusion}

With judicious use of life-experience credits, equivalency-exams, and an average of ten courses at $\$ 75.00$ a credit hour, plus the costs of texts, you can piece together the 120 necessary credit hours for a baccalaureate for less than $\$ 4,000$. For someone really on top of his or her game, this sum (which is one-fifth of what was projected above) could even be cut in half.

It is all up to you. If you have the will, you can succeed beyond your expectations. With some work and time, build your academic file and keep it close. The limits you face are those you place upon yourself. There is always 
a way to piece your college education together behind bars. Mind the thoughts of William M. Bulger: "There is never a better measure of what a person is when he is absolutely free to choose."

\section{REFERENCES}

Armouri, S. (2002, August 29). "Downturn Goes Easier on College-Educated Workers." USA Today, p. B1.

Ayers, D. et al. (1980). Effects of University of Victoria Program: A Post Release Study. Ottawa: Ministry of the Solicitor General of Canada.

Bear, J., and Bear, M. (1999). College Degrees by Mail and Modem. Berkeley: Ten Speed Press.

Blumenstein, A., and Cohen, J. (1979). "Control of Selection Effects in the Evaluation of Social Problems." Evaluation Quarterly, 3:4, 585-608.

Clark, D. (1991). Analysis of Return Rates of the Inmate College Program Participants. Albany, NY: New York Department of Correctional Services.

Duguid, S. (1981). "Rehabilitation through Education: A Canadian Model." In L. Morin (Ed.), On Prison Education (pp. 43-54). Ottawa: Canadian Publishing Centre.

Gaither, C.C. (1980). An Evaluation of the Texas Department of Corrections'Junior College Program. Monroe: Northeast Louisiana University.

Harer, M. (1995, December 9). Recidivism among Federal Releasers in 1987: A Preliminary Report. Washington DC: Federal Bureau of Prisons, Office of Research and Evaluation.

Haralson, D., and Tian, Q. (2002, March 12). "USA Today Snapshots: Worth of a Degree." USA Today, p. B1.

Holloway, J., and Moke, P. (1986). "Post Secondary Correctional Education: An Evaluation of Parole Performance." Unpublished paper available from 1326 Pyle Center, Wilmington College, Wilmington $\mathrm{OH}, 45177$.

Ross, R., and McKay, H. (1978). "Behavioural Approaches to Treatment in Corrections: Requiem for a Panacea." Canadian Journal of Criminology, 20:2, 279-95.

University of Wisconsin. (1995). University of Wisconsin Prison Day: Students "Doing Time For Education." Associated Students of Madison.

Western, B., and Pettit, R. (2000). "Incarceration and Racial Inequality in Men's Employment." Industrial Labor Relations, 54: 3-16.

Jon Marc Taylor is co-editor of this volume of the Journal of Prisoners on Prisons with a sustained contribution of articles on prison education published in JPP, the Journal of Correctional Education, and elsewhere. He recently published the second edition of Prisoners' Guerrilla Handbook to Correspondence Programs in the United States and Canada (Biddle Publishing, 2002). He can be reached at 503273, 1115 East Pence Road, Cameron, MO 64429. 